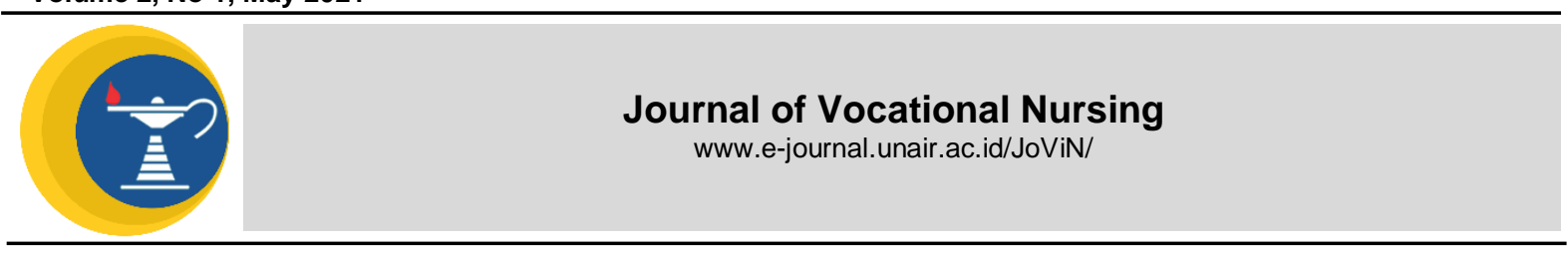

\title{
RELATIONSHIP OF BREASTFEEDING WITH GROSS AND FINE MOTOR SKILLS DEVELOPMENT IN INFANT 6-12 MONTHS
}

\section{Rukanah}

Research Report

Akademi Kebidanan Mandiri,Gresik

\section{ABSTRACT}

Introduction: WHO recommends exclusive breastfeeding for newborn sup to six month sofage. Exclusive breastfeeding is given forinfantonlybreastmilk, not given food or other fluids, evenwater, except for vitamins, minerals, ormedicines. Exclusive breast feeding has a positive effect on the motor development of infants in earlylife. This study aimed to determine the relationship between breastfeeding with gross and fine motor skills development in infants 6-12 months. Methods: The design was a crosssectional study, a total sample of 43 infants with a simple random sampling technique. The research instrument used questionnaires and interviews to obtain data on exclusive breastfeeding, to measure gross motor and fine motor skills development using a checklist form based on Denver II. Data analysis used the Chi-square test with a significance level of $\alpha<0.05$. Results: The results showed a significant relationship between breastfeeding and gross motor skills development in infants $(p=0,000)$, and there was no relationship between breastfeeding and fine motor skills development in infants $(p=0,191)$. Conclusion: The study concludes that there is the level of knowledge and readiness of mothers in giving exclusive breastfeeding was still lacking and it could cause gross motor skills in infants to experience delays, although not significantly. By providing breastfeeding, it can provide many benefits for mothers and babies, so it is hoped that mothers will increase their knowledge about giving breastfeeding exclusively and implementing it.

\section{ARTICLE INFO}

Received April 19, 2021

Accepted May 29, 2021

Online May 31, 2021

*Correspondence:

Rukanah

*Email:

rukanah1986@gmail.com

\section{Keywords:}

Breastfeeding, Fine Motoric, Gross Motoric

\section{INTRODUCTION}

Gross motor and fine motor skills development are parameters of an infant's ability to move his limbs. Infant development must receive early attention because it is an early start and can support the achievement of general health, self-confidence, stress, and social development at a later stage of life (Santrock, 2011). Age 0-5 yearsis a period of growth and development that is very crucial for humans. This age is called the golden age period of growth for a child. This period is the basis for skill sand intelligence that affect adulthood.

Development is increased of structure and function of the body more complex in the ability of gross and fine motion, speech, and language, as well as socialization and independence (Saputri, 2020). Based on Jean Piaget's theory of development, the age of $0-2$ years is a phase of motor-sensory development (Sembiring, 2019). This phase is related to the motor development skill of infants, namely the reaction to stimulation and movement of their limbs. Gross motor skill development is achievement related to large muscles the ability to crawl, stand and walk. Fine motor skill development has more to do with reactions to stimuli or objects around as grasping, sucking, and related to smooth muscle activity .

Motor skill development is time to be considered because used to detect the presence or absence of developmental delays. Delays in the development of gross or fine motoric skills greatly affect cognitive abilities in the future.

Breast milk is the food that babies need until the age of 6 months. Breastfeeding babies for six months without any additional is called exclusive breastfeeding. Exclusive breastfeeding is very beneficial for babies, namely: increasing endurance, increasing intelligence, vision, and reduce the risk of disease. Besides, exclusive breastfeeding makes the baby's development very well in the first six months or even beyond the age of 6 
months Breast milk is the food that babies need until the age of 6 months. Breastfeeding babies for six months without any additional is called exclusive breastfeeding. Exclusive breastfeeding is very beneficial for babies, namely: increasing endurance, increasing intelligence, vision, and reduce the risk of disease. Besides, exclusive breastfeeding makes the baby's development very well in the first six months or even beyond the age of 6 months (Bernard et al., 2013; Deoni et al., 2013).

The World Health Organization (WHO) and the United Nations Children's Fund (UNICEF) have made a declaration known as the Innocenti Declaration. This declaration aims to promote and support breastfeeding. These declarations are evidence-based on scientific of the benefits of breastfeeding on infant resistance, growth, and development (Kemenkes RI, 2014).

In Indonesia, the coverage of infants are exclusively breastfeeding in 2019 is $67,7 \%$. The highest coverage of exclusive breastfeeding in Indonesia was West Nusa Tenggara province at $86,3 \%$, while the lowest coverage of exclusive breastfeeding was West Papua province at $41,1 \%$. The East Java Province is in 3rd position at 78,3\% (Kemenkes RI, 2020).

East Java Province Health Profile data in 2019, shows that the highest exclusive breastfeeding coverage is in Pacitan Regency at $96,4 \%$, while the lowest exclusive breastfeeding coverage is in Bangkalan Regency at $46,9 \%$. The coverages of exclusive breastfeeding in Lamongan Regency is in the 24th position out of 38 Regencies / Cities in East Java, amounting to $78,7 \%$ (Dinas Kesehatan Provinsi Jawa Timur, 2020).

The development of gross and fine motor skills influenced by more factors is the nutritional status during pregnancy and after birth (Chiu et al., 2011). The nutritional status of pregnancy affects the process of brain cell formation's role in the development of an infant's brain after birth. Birth weight is the keys factor for infant development is a predictor of life expectancy and future health of children (Piek et al., 2008; Grace et al., 2017).
Another nutritional factor that affects the motor development of an infant is breastfeeding. Breast milk is the source of food for infants, which contains nutrients that are following the infant's digestion and needs. Breastfeeding alone for six months can improve the motor development of the baby. Besides being related to meeting nutritional needs, breastfeeding is related to the emotions between mother and child important role in the mental and motor development of the baby (Dee et al., 2007; Baumgartel et al., 2020).

Several research results show that there is a significant relationship between exclusive breastfeeding and infant motor development, and also show that non-exclusive breastfeeding has a 5 times risk of abnormal gross motor development compared to infants who are exclusive breastfeeding (Deoni et al., 2013; Riah Ayu et al., 2021). Based on these descriptions, interested to know the development of gross and fine motor skills in infants 6-12 months.

\section{MATERIALS AND METHODS}

The research design was crosssectional. The research was conducted from January to March 2019 in Gempol Pading Pucuk, Lamongan Regency. The study population was all infants aged 6-12 months. The research sample was 43 infants, taken by a simple random sampling technique.

The collection of data on exclusive breastfeeding used questionnaires and interviews, while to determine gross and fine motor development, it was measured using a checklist form based on the Denver II according to age. Univariate analysis to determine the frequency distribution of characteristics respondents, the bivariate analysis used the Chi-square test with a significance level of $\alpha<$ 0,05 , to determine the relationship between breastfeeding and the infant's gross motor and fine motoric development. 


\section{RESULTS}

Table 1. Characteristics of Infants $6-12$ Months $(n=43)$.

\begin{tabular}{llcc}
\hline No & \multicolumn{1}{c}{ Characteristics } & Frequency & Percentage \\
\hline 1 & Gender : & & \\
& Male & 24 & 55,8 \\
& Female & 19 & 44,2 \\
\hline 2 & Nutrition Status : & & \\
& Normal & 28 & 65,1 \\
& Underweight & 14 & 32,6 \\
& Less Underweight & 1 & 2,3 \\
\hline 3 & Child Number & & \\
& 1 & 25 & 58,1 \\
& 2 & 15 & 34,9 \\
& $>3$ & 3 & 7,0 \\
\hline
\end{tabular}

The characteristics of respondents showed that most infants $(55,8 \%)$ were male, most infants $(65,1 \%)$ had normal nutritional status, and most infants $(58,1 \%)$ were first children.

Table 2. Distribution of Breastfeeding History for Infants 6-12 Months $(n=43)$

\begin{tabular}{cccc}
\hline No & Exclusive Breastfeeding & Frequency & Percentage \\
\hline 1. & Exclusive breastfeeding & 22 & 51,2 \\
2. & Not Exclusive Breastfeeding & 21 & 48,8 \\
\hline & Total & 43 & 100
\end{tabular}

The table shows that most infants $(51,2 \%)$ received exclusive breastfeeding, and the rest did not receive exclusive breastfeeding.

Table 3. DistributionofGross Motor Skill Development forlnfants 6-12 Months $(n=43)$

\begin{tabular}{|c|c|c|c|}
\hline No & Gross Motor Development & Frequency & Percentage \\
\hline 1. & Normal & 21 & 48,8 \\
\hline 2. & Suspect & 12 & 27,9 \\
\hline 3. & Delay & 10 & 23,3 \\
\hline & Total & 43 & 100 \\
\hline
\end{tabular}

Table 3 shows that almost half of the infants $(48,8 \%)$ had normal gross motor skill development and only a small proportion of infants $(23,3 \%)$ had gross motor skill development in the delayed category.

Table 4. Distributionof Fine Motor Skill Development for Infants 6-12 Months( $n=43)$

\begin{tabular}{cccc}
\hline No & Fine Motor Development & Frequency & Percentage \\
\hline 1. & Normal & 22 & 51,2 \\
2. & Suspect & 11 & 25,6 \\
3. & Delay & 10 & 23,3 \\
\hline & Total & 43 & 100 \\
\hline & Table 4 shows a majority of infants $(51,2 \%)$ had normal fine motor skill development, and only
\end{tabular}
a small proportion of infants $(23,3 \%)$ had fine motor skill development in the delay category.

Table 5. Cross tabulation of breastfeeding and gross motor skill development for infants 6-12 months $(n=43)$

\begin{tabular}{|c|c|c|c|c|c|c|c|c|c|c|}
\hline \multirow{3}{*}{ Breastfeeding } & \multicolumn{8}{|c|}{ Gross Motor Development } & \multirow{3}{*}{$p$} & \multirow{3}{*}{$x^{2}$} \\
\hline & \multicolumn{2}{|c|}{ Normal } & \multicolumn{2}{|c|}{ Suspect } & \multicolumn{2}{|c|}{ Delay } & \multicolumn{2}{|c|}{ Total } & & \\
\hline & $\mathrm{n}$ & $\%$ & $\mathrm{n}$ & $\%$ & $\mathrm{n}$ & $\%$ & $\mathrm{n}$ & $\%$ & & \\
\hline Exclusive breastfeeding & 20 & 90,9 & 1 & 4,5 & 1 & 4,5 & 22 & 100 & 0,000 & 31,918 \\
\hline Not Exclusive Breastfeeding & 1 & 4,8 & 11 & 52,4 & 9 & 42,9 & 21 & 100 & & \\
\hline
\end{tabular}

Table 5 shows almost all infants with exclusive breastfeeding have normal gross motor skill development $(90,9 \%)$, and most infants with not exclusive breastfeeding have gross motor skill development in the suspect category $(52,4 \%)$. Chi-square test results obtained $p=0,000$, then $p<0,05$, 
meaning is a significant relationship between breastfeeding and gross motor skill development in infants 6-12 months.

Table 6. Cross tabulation of breastfeeding and gross motor skill development for infants 6-12 months $(n=43)$

\begin{tabular}{|c|c|c|c|c|c|c|c|c|c|c|}
\hline \multirow{3}{*}{ Breastfeeding } & \multicolumn{8}{|c|}{ Cross Motor Development } & \multirow{3}{*}{$\mathrm{p}$} & \multirow{3}{*}{$x^{2}$} \\
\hline & \multicolumn{2}{|c|}{ Normal } & \multicolumn{2}{|c|}{ Suspect } & \multicolumn{2}{|c|}{ Delay } & \multicolumn{2}{|c|}{ Total } & & \\
\hline & $\mathrm{n}$ & $\%$ & $\mathrm{n}$ & $\%$ & $\mathrm{n}$ & $\%$ & $\mathrm{n}$ & $\%$ & & \\
\hline Exclusive breastfeeding & 14 & 63,6 & 5 & 22,7 & 3 & 13,6 & 22 & 100 & 0,191 & 3,306 \\
\hline Not Exclusive Breastfeeding & 18 & 38,1 & 6 & 28,6 & 7 & 33,6 & 21 & 100 & & \\
\hline
\end{tabular}

Table 6 shows most infants with exclusive breastfeeding had normal fine motor skill development $(63,6 \%)$, and only the majority of infants with not exclusive breastfeeding had fine motor skill development in the delay category $(33,3 \%)$. Chi-square test results obtained $p=0,191$, then $p>0,05$, meaning there is no relationship between breastfeeding and fine motor skill development in infants 6 12 months.

\section{DISCUSSION}

Breastmilk is the only food accept and digest by infants under six months of age. Breast milk contains nutrients needed to support the growth and development of infants. Exclusive breastfeeding has a positive effect on the motor skill development of infants in the early months of life. WHO has recommended exclusive breastfeeding for newborns up to 6 months of age. Exclusive breastfeeding means the infant gave breast milk only, does not get any other food and even water, except vitamins, minerals, or drugs (Dee et al., 2007; Diana, 2010).

Children had characteristics that distinguish them from adults, are growing and developing since conception, and ending when they enter adolescence. Children show growth and development characteristics according to their age. Growth is the increase in the size and number of cells or can interpret as an increase in physical size and body structure so measured in units of length and weight. Development is adding more complex body functions in gross motor skills, fine motor skills, speech skills, socialization, and independence (Saputri, 2020). The growth coincides with development. In contrast to growth, development occurs due to the interaction of the maturity of the central nervous system with the organs that affect it (Saraswati and Muwakhidah, 2018; Riah Ayu et al., 2021).

The development of a child is influenced not only by genetic factors but also environmental factors that are no less important. Health education is more important to parents, especially mothers, to provide the best nutrition for children from early in life (Jalal, 2011). At the beginning of life, babies need adequate nutrition so that their growth and development process can run optimally (Partipasari and Salam, 2019). Breast milk is a complex biological fluid that contains all the nutrients and nutrients needed for a child's growth and development. Its nature is breast milk which is very easily absorbed, makes the most nutrient that is most suitable, and meets the requirements for infant growth and development (Victora et al., 2016).

Infants exclusive breastfeeding can grow and develop optimally and don't get sick easily. Exclusive breastfeeding reduces the mortality rate from infectious diseases in infants under three months of age by $88 \%$. Exclusive breastfeeding can also reduce the risk of obesity and chronic disease (The Lancet, 2016). Babies who are susceptible to disease will tend to experience growth and development disorders, including motor development (Shonkoff et al., 2012).

The results showed that $42,9 \%$ of infants did not receive exclusive breastfeeding. Many factors cause babies not to get exclusive breastfeeding. Based on results interviews with parents or caregivers, this is large to the lack of knowledge of mothers about the importance of exclusive breastfeeding and correct breastfeeding techniques. Lack of knowledge about proper breastfeeding techniques results in mothers feeling milk production and not confidently capable of breastfeeding. Besides, the working mother's busyness factor also causes the baby not to get breast milk exclusively.

In gross motor skill development, it finds that $48,8 \%$ of infants developed normally, and $51,8 \%$ of infants experienced suspected and delayed motor skill development. Gross motor skill development in the suspect and delay categories does not mean that the infants cannot do anything, but babies can still do activities like other children, only having a minor delay or can say the infants have not reached gross motor skill development accord to his age (Dee et al., 2007).

This study findingis a significant relationship between exclusive breastfeeding and gross motor skill development in infants 6- 
12 months. Gross motor skill development is a crucial achievement as crawling, sitting, standing, or walking that are easily observed and observed directly. Motor skill development is the development of control body movements through coordinated activities between the nervous system, muscles, brain, and spinal cord (Santrock, 2011). Motor development consists of gross motor and fine motor skills. Gross motor skills are body movements that use larges muscles or all body parts are affected by the maturity of the infants (Dee et al., 2007).

The factor of infant nutritional intake is a direct factor as a critical role in the development of the baby. Nutrition affects the development of the baby's brain, from the fourth week of conception until the two ages. Nutritional needs consist of macronutrients (carbohydrates, proteins, fats) and micronutrient needs (vitamins and minerals) (Walker, 2007). Nutrition can affect the anatomical structure of the brain that affects central nerve cells. Nutrition status also affects brain chemistry, the forming process of the number of neurotransmitters, the number of receptors, and the number of transported neurotransmitters. Nutrients that have an essential role in the development process of brain neuron cells for the provision of infant intelligence are fatty acids (Leventakou et al., 2015; Mohamed, Ochola and Owino, 2018).

The results showed no relationship between exclusive breastfeeding and fine motor skill development in infants6-12 months. Fine motor skills are movements that use smooth muscles or certain parts of the body, are influenced by the baby's opportunity to practice, such as the ability to move objects from the hand, cross, arrange blocks, cut, write, and so on. Fine motor skill development differs from gross motor skill development with critical achievements that are easy to observe(Diana, 2010; Dinkel and Snyder, 2020).

In the early of life, parents more attention to the gross motor skill development of an infant. In general, parents feel more worried about the infant not achieving gross motor skill development such as crawling, sitting, standing or walking because considered to be more important things in the baby's growth and development (Kumwenda et al., 2018). Therefore, usually, the stimulus from parents is more directed to support gross motor development. Also, the assessment of fine motor development, apart from being more complex, is greatly influenced by the baby's mood and self-confidence when running a series of tests. Babies who are tired, fearful, or will refuse to properly perform fine motor skill development tests (Piek et al., 2008; Leventakou et al., 2015).

Apart from nutritional factors, the factor that greatly influences infants' development is parenting. Parenting is an act of caring for infants carried repeatedly becomes a habit, the parenting style is a relevant link to measure nutritional status in the long term. Some research results show that babies who don't get much stimulation have a brain size that is $30 \%$ smaller than babies who get optimal stimulation (Oddy et al., 2011; O'Leary et al., 2019).

\section{CONCLUSION}

The conclusion study showed a relationship between breastfeeding and gross motor skill development, but there was no relationship between breastfeeding and fine motor skill development in infants 6-12 months. The exclusive breastfeeding is very important for infant growth and development, besides it can reduce mortality and obesity in infants. The results of the study stated that the level of knowledge and readiness of mothers in giving exclusive breastfeeding was still lacking and it could cause gross motor skills in infants to experience delays, although not significantly. By providing breastfeeding, it can provide many benefits for mothers and babies, so it is hoped that mothers will increase their knowledge about giving breastfeeding exclusively and implementing it.

It is necessary to do further research on the relationship of breastfeeding with the development of gross and fine motor skills with a larger of samples and age criteria, as well as consideration of other variables that affect gross and fine motor skill development so is expected to get a more detailed description of the results.

\section{REFERENCES}

Baumgartel, K. et al. (2020) 'The contributions of fetal growth restriction and gestational age to developmental outcomes at 12 months of age: A cohort study', Early Human Development, 142, p. 104951. doi: 10.1016/j.earlhumdev.2020.104951.

Bernard, J. Y. et al. (2013) 'Breastfeeding Duration and Cognitive Development at 2 and 3 Years of Age in the EDEN Mother-Child Cohort', The Journal of Pediatrics, 163(1), pp. 36-42.e1. doi: 10.1016/j.jpeds.2012.11.090.

Chiu, W.-C. et al. (2011) 'Duration of breast feeding and risk of developmental delay in Taiwanese children: a nationwide birth cohort study', Paediatric and Perinatal Epidemiology, 25(6), pp. 519-527. doi: 10.1111/j.1365-3016.2011.01236.x. 
Dee, D. L. et al. (2007) 'Associations Between Breastfeeding Practices and Young Children's Language and Motor Skill Development', Pediatrics, 119(Supplement 1), pp. S92-S98. doi: 10.1542/peds.2006-2089N.

Deoni, S. C. L. et al. (2013) 'Breastfeeding and early white matter development: A crosssectional study', Neurolmage, 82, pp. 77-86. doi: 10.1016/j.neuroimage.2013.05.090.

Diana, F. M. (2010) 'Pemantauan perkembangan anak balita', Jurnal Kesehatan Masyarakat Andalas, 4(2), pp. 116-129. doi: 10.24893/jkma.v4i2.79.

Dinas Kesehatan Provinsi Jawa Timur (2020) Profil Kesehatan Provinsi Jawa Timur Tahun 2019, Dinas Kesehatan Provinsi Jawa Timur. Available at: https://dinkes.jatimprov.go.id/userfile/do kumen/Profil Kesehatan Jatim 2019.pdf (Accessed: 1 March 2021).

Dinkel, D. and Snyder, K. (2020) 'Exploring gender differences in infant motor development related to parent's promotion of play', Infant Behavior and Development, 59, p. 101440 . doi: 10.1016/j.infbeh.2020.101440.

Grace, T. et al. (2017) 'Breastfeeding and motor development: A longitudinal cohort study', Human Movement Science, 51, pp. 9-16. doi: 10.1016/j.humov.2016.10.001.

Jalal, F. (2011) 'Tantangan pembangunan kesehatan dan gizi dalani upaya peningkatan kualitas SDM'. CPI.

Kemenkes RI (2014) 'Situasi dan Analisis ASI Eksklusif', Pusat Data Dan Informasi Kementerian Kesehatan RI. Available at: https://pusdatin.kemkes.go.id/resources/ download/pusdatin/infodatin/infodatinasi.pdf (Accessed: 1 March 2021).

Kemenkes RI (2020) Profil Kesehatan Indonesia Tahun 2019, Kementerian Kesehatan RI. Available at: https://pusdatin.kemkes.go.id/resources/ download/pusdatin/profil-kesehatanindonesia/Profil-Kesehatan-indonesia2019.pdf (Accessed: 1 March 2021).

Kumwenda, C. et al. (2018) 'Association between breast milk intake at 9-10 months of age and growth and development among Malawian young children', Maternal \& Child Nutrition, 14(3). doi: $10.1111 / \mathrm{mcn} .12582$.

Leventakou, V. et al. (2015) 'Breastfeeding duration and cognitive, language and motor development at 18 months of age: Rhea mother-child cohort in Crete, Greece', Journal of Epidemiology and Community Health, 69(3), pp. 232-239. doi: 10.1136/jech-2013-202500.

McCrory, C. and Murray, A. (2013) 'The Effect of Breastfeeding on Neuro-Development in Infancy', Maternal and Child Health Journal, 17(9), pp. 1680-1688. doi: 10.1007/s10995-012-1182-9.

Mohamed, M. J., Ochola, S. and Owino, V. O. (2018) 'Comparison of knowledge, attitudes and practices on exclusive breastfeeding between primiparous and multiparous mothers attending Wajir District hospital, Wajir County, Kenya: a cross-sectional analytical study', International Breastfeeding Journal, 13(1), p. 11. doi: 10.1186/s13006-0180151-3.

O'Leary, N. et al. (2019) 'Antenatal depression and the impact on infant cognitive, language and motor development at six and twelve months postpartum', Early Human Development, 134, pp. 41-46. doi: 10.1016/j.earlhumdev.2019.05.021.

Oddy, W. H. et al. (2011) 'Breastfeeding and early child development: a prospective cohort study', Acta Paediatrica, 100(7), pp. 992-999. doi: 10.1111/j.16512227.2011.02199.x.

Partipasari, B. and Salam, A. (2019) 'Hubungan Pemberian Asi Eksklusif Dengan Perkembangan Motorik Kasar Bayi Umur 7-12 Bulan Di Wilayah Kerja Puskesmas Tanjung Karang Kota Mataram', Jurnal Gizi Prima (Prime Nutrition Journal), 2(2), pp. 154-160. doi: 10.32807/jgp.v2i2.100.

Piek, J. P. et al. (2008) 'The role of early fine and gross motor development on later motor and cognitive ability', Human Movement Science, 27(5), pp. 668-681. doi: 10.1016/j.humov.2007.11.002.

Riah Ayu, P. et al. (2021) 'Hubungan Antara Pola Pemberian ASI Terhadap Perkembangan Motorik Kasar Pada Bayi Usia 6-11 Bulan di Puskesmas Rappokalling Kota Makassar', Window of Public Health Journal, pp. 359-369. doi: 10.33096/woph.v1i4.164.

Santrock, J. W. (2011) Masa Perkembangan Anak Buku 2 Edisi 11. Jakarta: Salemba Humanika.

Saputri, N. (2020) Modul Teori Asuhan Neonatus, Bayi, Balita Dan Anak Pra Sekolah. Yogyakarta: Pustaka Pranala.

Saraswati, A. and Muwakhidah, M. (2018) 
'Perkembangan Motorik antara Balita Usia 7-24 Bulan Asi Eksklusif dan Non Asi Eksklusif Di Puskesmas Mantingan Kabupaten Ngawi', Jurnal Kesehatan, 11(1), pp. 24-31. doi: 10.23917/jk.v11i1.7001.

Sembiring, J. B. (2019) Buku Ajar Neonatus, Bayi, Balita, Anak Pra Sekolah. Yogyakarta: Deepublish.

Shonkoff, J. P. et al. (2012) 'An Integrated Scientific Framework for Child Survival and Early Childhood Development', PEDIATRICS, 129(2), pp. e460-e472. doi: 10.1542/peds.2011-0366.

The Lancet (2016) 'Breastfeeding: achieving the new normal', The Lancet, 387(10017), p. 404. doi: 10.1016/S01406736(16)00210-5.

Victora, C. G. et al. (2016) 'Breastfeeding in the 21st century: epidemiology, mechanisms, and lifelong effect', The Lancet, 387(10017), pp. 475-490. doi: 10.1016/S0140-6736(15)010247.

Walker, M. (2007) 'International Breastfeeding Initiatives and their Relevance to the Current State of Breastfeeding in the United States', Journal of Midwifery \& Women's Health, 52(6), pp. 549-555. doi: 10.1016/j.jmwh.2007.06.013. 